\title{
Adagloxad Simolenin
}

National Cancer Institute

\section{Source}

National Cancer Institute. Adagloxad Simolenin. NCl Thesaurus. Code C99766.

A carbohydrate-based immunostimulant comprised of the Globo $\mathrm{H}$ hexasaccharide 1

(Globo $\mathrm{H}$ ) epitope linked to the immunostimulant carrier protein keyhole limpet hemocyanin (KLH), with potential antineoplastic activity. Upon administration of adagloxad simolenin, the carbohydrate antigen Globo $\mathrm{H}$ may stimulate a cytotoxic $\mathrm{T}$ lymphocyte $(\mathrm{CTL})$ response against Globo $\mathrm{H}$-expressing tumor cells, thereby decreasing tumor cell proliferation. Globo $\mathrm{H}$ is a tumor associated antigen (TAA) commonly found on a variety of tumor cells including breast cancer cells. KLH improves antigenic immune recognition and T-cell responses. 